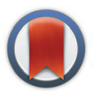

CrossMark

\&lick for updates

Cite this: Org. Chem. Front., 2015, 2 753

DOI: $10.1039 / c 5 q 090018 b$

rsc.li/frontiers-organic

\section{Correction: Boronic esters of corannulene: potential building blocks toward icosahedral supramolecules}

Sara Da Ros, Anthony Linden, Kim K. Baldridge* and Jay S. Siegel*

Correction for 'Boronic esters of corannulene: potential building blocks toward icosahedral supramolecules' by Sara Da Ros et al., Org. Chem. Front., 2015, DOI: 10.1039/c5qo00009b.

During production, the wrong Fig. 14 was inserted. The authors are happy to have the opportunity to correct this production error. The correct Fig. 14 is given below.
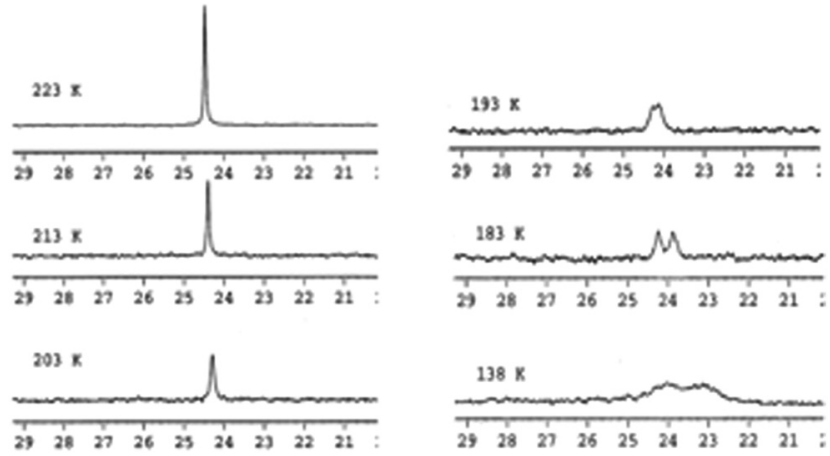

Fig. 14 VT-NMR of 3 in dichlorofluoromethane- $d^{1}(138-223 \mathrm{~K})$.

The Royal Society of Chemistry apologises for these errors and any consequent inconvenience to authors and readers. 